\title{
舌癌の発生部位からみた臨床病態的検討
}

\author{
原田＼cjkstart直－田中浩二・清見原正騎 · 前田 耕 作 \\ 井上伸吾 $\cdot$ 辻野哲弘・伊藤良明 $\cdot$ 片 光司 \\ 中島英元 $\cdot$ 山本道直·杉山 勝 $\cdot$ 石川武憲
}

\section{Clinico-statistical investigation of occurrence sites of tongue cancer}

\author{
Tadashi Harada $\cdot$ Kohji Tanaka $\cdot$ Masaki Kiyominara $\cdot$ Kohsaku Maeda \\ Shingo Inoue $\cdot$ Tetsuhiro Tsujino $\cdot$ Yoshiaki Itoh $\cdot$ Kohji Kata \\ Hidemoto NaKajima $\cdot$ Michinao Yamamoto $\cdot$ Masaru Sugiyama $\cdot$ Takenori Ishikawa
}

\begin{abstract}
Ninety cases of tongue cancer (1975-1995) were clinicostatistically investigated according to occurrence site, defind as the forward $1 / 3$, central $1 / 3$, and back $1 / 3$ of the tongue. 1) Eighty-five percent of patients with cancers arising in the forward $1 / 3$ and central $1 / 3$ of the tongue sought medical consultation within one year after becoming aware of the lesion. However, in patients with cancer of the back $1 / 3$, of the tongue one year or more was required before seeking medical consultation in about half of the cases.

2 ) Cases arising in the back $1 / 3$ tended to increase with progression of stage from $I$ to $\mathrm{N}$.

3 ) The 5 -year survival rate of patients with tongue cancer occurring in the back $1 / 3$ was significantly lower than those of patients with cancer of the foward $1 / 3$ and central $1 / 3$. Among patients with stage IV disease, $75 \%$ of those with tongue cancer of the back $1 / 3$ died within one year after consultation, i.e., cases arising in the back $1 / 3$ of the tongue had a very bad prognosis.
\end{abstract}

Key words: tongue cancer (舌癌), occurrence site (発生部位), survival rate (生存率)

\section{緒}

口腔癌の中で最も発生頻度の高い舌癌は, 早期に発 見されやすいにもかかわらず, 治療結果は必ずしも良 くない.これは, 舌組織における縦, 横, 垂直に配列す る各層の舌筋や血管などの走行に伴う構築が踈であり, また複雑な舌運動が, 腫瘍の拡大や伸展に働く因子に なると考えられるからである.すなわち, 繊細な舌運 動機能に対応すべき組織の構築や脈管, 神経などの分 布に関する解剖学的組織構築の違いにより, 発生病態

\section{広島大学歯学部口腔外科学第二講座}

(主任 : 石川武憲教授)

Department of Oral and Maxillofacial Surgery II , Hiroshima University School of Dentistry (Chief: Prof. Takenori Ishikawa)

受付日：平成 8 年 1 月 9 日
には大きな差が生じるはずであり，Seward は，舌癌 の後方例は, 伸展・波及しやすく，また転移の生じや すいことを述べていたが，われわれも，各種症例から これに賛同すべき現象をみてきた，すなわち，舌癌の 発生部位の違いや同部における関与因子を考えるとき, 舌の前, 中, 後方の分類もこれらの関与因子となり得 る.この点から, 発生病態の差違や予後に関する検索 も必要となるが,これらの報告はないようである。解 剖学的構築因子と舌癌発生や予後の関係を検索する前 段階として，以上の考えの是非を現象的に知る要があ り, 今回, 舌癌の発生部位と病態の相関を再検討した。

\section{被験例と検討項目}

1975 年 12 月から 1995 年 4 月までの 19 年 4 か月間 に当科で対処した舌癌の一次症例 90 例を対象に，前 


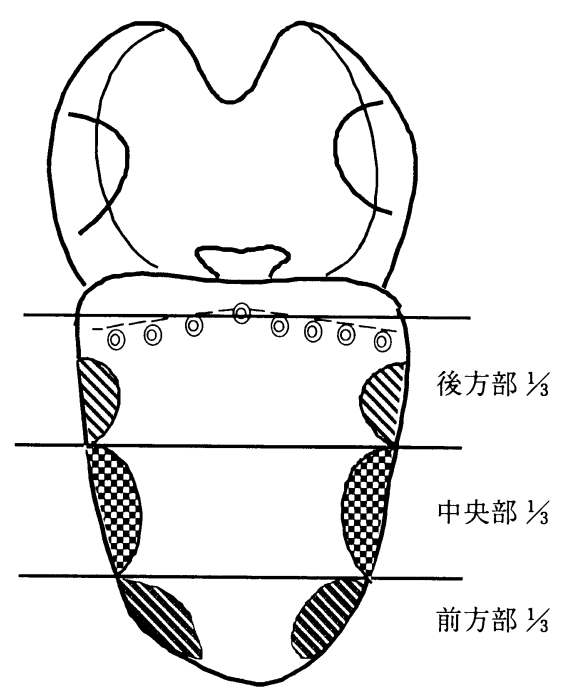

図 1 発生部位の分類

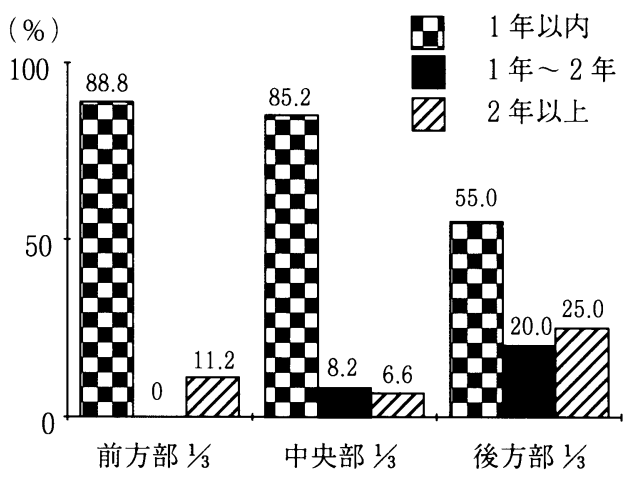

図 2 発生部位別の受診時期間

述の観点から舌癌の発生部位と予後の関係，またこ れら発生部位からみた臨床病態を検討した。このため, 舌分界溝より前の舌体を前方部 $1 / 3$, 中央部 $1 / 3$ および後 方部 $1 / 3 に 3$ 分割して (図 1 ), これら部位別に発生した 舌癌の受診までの期間, 発生頻度, 予後などにつき検 討した。なお, 部位の設定で, 後方部の後端は舌分界 溝とすべきであるが, 盲孔を横走する仮想線と最外側 の有郭乳頭間の距離は, 舌を前方率引して直視下にお くと, われわれの計測した 25 例では，平均 $4.3 \mathrm{~mm}$ で あり,この仮想線は舌体後端部の便宜的分画線として, 臨床的に応用可能と考えている. 発生部位の判定は, 腫瘍占有部の中心部位を発生部位とした。

\section{結}

\section{果}

1. 受診までの期間：舌縁, 舌下面例において, 患 者が自覚後受診するまでの期間を発生部位別に比較し た (図 2 ). 前方と中央に発生した例では, ともに約 85
病期

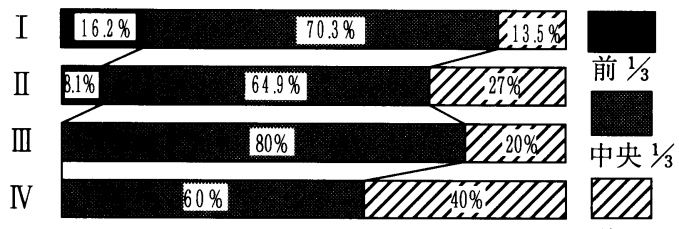

後 $1 / 3$

図 3 病期別の部位的分類

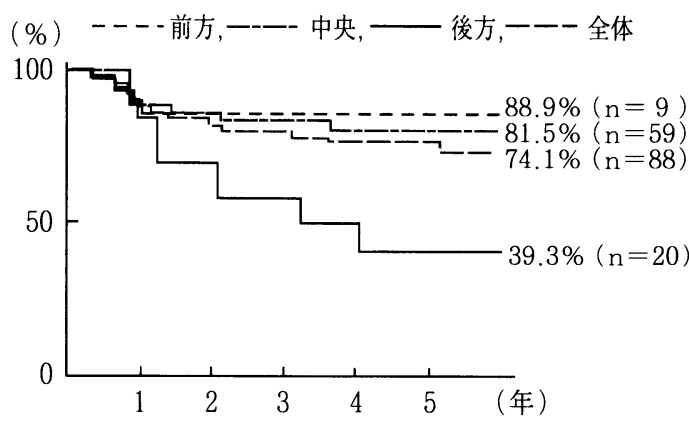

図 4 発生部位別 5 年生存率

$\%$ 以上が 1 年以内に受診していたのに対し, 後方の発 生例では 1 年以内の受診は $55.0 \%, 1$ 年〜 2 年の間が $20.0 \%, 2$ 年以上の例は $25.0 \%$ であった。

2 . 発生頻度 : 上記の舌の発生部位別に各病期で の発生頻度をみると（図 3 ), 病期 I では，おのおの 16.2\%, 70.3\%および 13.5\%であった。IIでは，おのお の $8.1 \%, 64.9 \%$ および $27.0 \%$, III では $0 \%, 80 \%$ お び $20 \%$, IVでは $0 \%, 60 \%$ および 40.0\%であり，後方 部に発生した例は, 病期の進行に伴い増加傾向を示し た。

3 . 部位別の予後：舌癌の発生部位別に5 年生存 率を検討すると, 前方部と中央部は, 各 $88.9 \%$ と 81.5 $\% に$ 対し, 後方部に発生した例は $39.3 \%$ と低く, 明ら かな差がみられた（図４）。ここで, 部位と治療法の関 係をみるため, 症例が多く, 治療法との関係を検討し うる病期 I, II 群を取り上げ, 放射線単独治療群で, 部位別 5 年生存率をみると, 前方部, 中央部で, おの おの $88.9 \%, 87.6 \%$ に対し, 後方部例の生存率は 63.7 \%で, 部位別の治療結果に明らかな差を認めた。さら に, 病期 IVでの後方部の発生例は， $75 \%$ が 1 年以内に 死亡しており, 全体例の病期 IV での 5 年累積生存率が 40.0\%であったことを考えると, 予後はより不良であっ た。

\section{考察}

1. 受診までの期間：後方に発生した例は, 前方 と中央に発生した例と比較し, より長い経過の後に受 
診していた. 後方部では, 病巣を自覚しても, 症状や 機能障害を認識しにくいことがある. 症状を十分認知 していても, 病気に対する不安感や恐怖感等の因子が 加わり，望ましい受診時期を逸することも多いようで ある. 受診期間と腫場の浸潤程度について, 佐藤らは, 症状の発現後, 来院までの期間と腫瘍の浸潤度との関 連性を報告しており ${ }^{1)}$, 発生部位が早期発見, 早期治 療に強く関係していることが窥われる.

2. 発生頻度：各病期で, 後方部に発生した頻度 は, 病期 IVでは増加傾向があり, 病期の進行との間に 関連性がみられた。一般的に舌癌は早期に発見されや すいにもかかわらず, 後方部は視覚的に確認が困難で あり，機能的にも障害の認識しにくいことから，早期 発見の機会を逸しやすく, 患者自身の認識程度が病期 を進行させる最大因子と考えられる。

3. 部位別の予後：われわれの分類した後方部に 発生した舌癌では, 予後は不良であった。この部は治 療の困難な部位であり, 治療法の選択により予後は左 右される. 近年, 早期癌に対して放射線療法より手術 療法の予後が良いという報告 $\left.{ }^{2}, 3\right)$ もあるが, 後方部 は切除範囲や機能保存の面で問題があり, 治療効果の 上がらないことが多く，予後を悪化させる原因となる. 当科では, 病期 I と II の早期例の大多数例で放射線単 独治療を行っているが, 治療結果をみると, 早期発見 例で, 前方部, 中央部の発生例に比較して, 後方部の 発生例は明らかに 5 年生存率が低かったことから, 発 生部位の組織構築の違いが子後に強く影響することが 推測された.さらに, 後方部発生例では部位的に早期 発見の機会を逸しやすいことも，予後不良の要因となっ ており, 舌癌では早期発見, 早期治療が重要な予後因 子になることを示している.腫場の完全な局所制御は 子後を決定する一大因子であり，また転移に大きく影 響することは周知の事実である. 斉藤は, 経過観察中 に転移のあった例の生存率は, なかった例の生存率の $1 / 2$ から $1 / 3$ と低いことを報告している ${ }^{4)}$. 一般に, 舌癌 はリンパ節転移を起こしやすく, $27 \%$ 67\%の例はリ ンパ転移をしたとの報告 5 ，6）やリンパ節転移率は腫 湯の大きさに相関していたとする報告 ${ }^{2)}$ ，また，腫瘍 の大きさよりも進展部位がより転移に関連する因子に なるとの報告もある7 ．われわれの結果も，この報告 に合致することを示唆している. 癌の発生部位によっ ては, 自覚や発見, 治療の評価等に困難を伴う。舌癌 は早期に発見されやすいことからすれば, 患者自身の 認識程度が病期を進行させる最大の因子であり，この
観点から, 社会的啓蒙により，さらに良い治療結果を 上げ得る可能性が高い. 治療の選択や予後を推測する 上で, 来院までの期間や初診時の原発巣の大きさに加 え, 特に舌縁, 舌下面例では, われわれの分類した発 生部位の違いも予後を左右する一大因子になると言え る. 今後, この観点から舌の解剖学的構築因子の関与 につき究明する必要があると考えている.

\section{結語}

約 20 年間に当科で対処した舌癌 90 例を発生部位別 に分類した.すなわち舌分界溝より前方部を前方部 $1 / 3$, 中央部 $1 / 3$ および後方部 $1 / 3$ に 3 等分し, 部位別の臨床病 態的検討を行った.

1. 自覚後受診するまでの期間は, 前方部と中央部 の発生例のうち, 約 $85 \%$ 以上が 1 年以内に受診した. 一方, 後方部に発生した例の約半数は 1 年以上経過し て受診していた。

2. 後方部での発生例の頻度は, 病期の進行に伴い 増加傾向があった。

3. 部位別の 5 年生存率では, 前方部と中央部の発 生例に比較し, 後方部の発生例は $39.3 \%$ で予後が悪く, また病期 $\mathrm{V}$ のうち後方部の発生例は, $75 \%$ が 1 年以内 に死亡し，予後はきわめて不良であった。

\section{参 考 文 献}

1）本田 学, 竹内和郎, 他：当教室における舌悪 性腫腸の統計的観察．耳鼻臨床 78: 增 $1 ； 969$ 9751985 .

2) 天笠光雄, 塩田重利, 他 : 舌癌の療法別治療成 績. J. Jpn. Soc. Cancer Ther., 20: 758-764 1985.

3）佐藤方信, 畠山節子, 他 : 生検例における舌癌 の病理学的検討. 日口外誌 29: 305-309 1983.

4) 斉藤 等, 佐藤文彦, 他 : わが教室 16 年間の舌 悪性腫瘍の統計的観察: 耳喉 54: 29-36 1983.

5) Krauze, C. J., Lee, J. G., et al: Carcinoma of the oral cavity. A comparison of the therapeutic modalities. Arch. Otolaryngol. 97: 354-358 1973.

6）堀内淳一, 奥山武雄, 他: 舌に対するラドンシー ド治療. 日医放誌 28: 344-354 1968.

7）大山和一郎 : 舌癌の原発巣進展範囲と再発 - 転 移様式に関する研究. 日耳鼻 87: 1483-1493 1984. 